\title{
Effect of Amphora coffeaeformis and Star anise as Dietary Supplementson the Immunity and Growth Performance of Broiler Chickens
}

\author{
Sherif Mohamed Shawky ${ }^{1 *}$, Said Ibrahim Fathalla ${ }^{1}$, Sahar Hassan Orabi ${ }^{2}$, Huda Hassan El-Mosalhi ${ }^{1}$, \\ and Ibrahim Said Abu-Alya ${ }^{1}$ \\ ${ }^{I}$ Department of Physiology, Faculty of Veterinary Medicine, University of Sadat City, Egypt. \\ ${ }^{2}$ Department of Biochemistry, Faculty of Veterinary Medicine, University of Sadat City, Egypt. \\ ${ }^{*}$ Corresponding author’s Email: shsh00076@yahoo.com ; ORCID:0000-0003-0629-7063
}

Received: 07 Nov. 2020

Accepted: 20 Dec. 2020

\begin{abstract}
The present study was designed to evaluate the impacts of daily dietssupplemented with Amphora coffeaeformis and Star anise on growth performance and immunity of Cobb broiler chickens. Amphora coffeaeformis is considered a potent free radical scavenger due to the presence of $\beta$-carotene and fucoxanthin, which are used widely as food additives. Star Anise has a natural antioxidant, which can also be used for the chemo-prevention of disease occurring due to oxidative deterioration. A total of 270 broiler chickens were divided into three groups, each with three replicates of 30 birds. The control group (G1) was given the basal diet, the Amphora group (G2) received Amphora in a dose of $1 \mathrm{~g} / \mathrm{Kg}$ in the ration, and the Star anise group (G3) received Star anise in a dose of $2 \mathrm{~g} / \mathrm{Kg}$ in the ration. The results indicated that Amphora and Star anise significantly improved the final body weight, weight gain, and feed conversion ratio, total white blood cells count, phagocytic activity percentage, phagocytosis index in plasma, IgM, $\mathrm{IgG}$, and $\mathrm{A} / \mathrm{G}$ ratio in serum. In addition, Amphora and Star anise significantly increased mRNA expression of hepatic growth hormone gene, insulin-like growth factor-1 (IGF-1) genes (IGF1), and mRNA expression of splenic interferon-gamma (INF- $\gamma$ ) and Interleukin 12 (IL-12p35) genes from broiler chickens, compared to the control group. In conclusion, the use of fed additives, such as Amphora coffeaeformisand Star anise in the diet of broiler chickens for 35 days was sufficient to improve broiler growth performance and could modulate their immunity.
\end{abstract}

Keywords: Amorpha coffeaeformis, Broiler chickens, Diet supplementation, Growth performance, Immunity, Star anise

\section{INTRODUCTION}

Global food production is facing a greater challenge than ever before. Protein in particular is one of the most important nutrients in animal and human life (FAO, 2018).

Broiler production as a source of protein has become an important issue in many growing countries. However, the recent increase in the costs of traditional feed was once a major contributor to net returns from the poultry business. Feed accounted for 70-80 percent of the total costs of poultry production (Bolu and Balogun, 2004). It was found that reducing feed costs using cheaper and more unconventional feed was once a required problem for commercial poultry production (Bhatta and Sharma, 2001). The feed additives are a collection of nutrients and non-nutrients compounds that help to increase the competence of feed usage and thus reduce the high feed costs. In recent years, these additives have played an important role as feed supplements for many purposes in poultry production (Zhang et al., 2009).

Microalgae were identified as microscopic, unicellular, and photosynthetic organisms and can grow in saline and freshwater which provide a rich supply of nutrients and biologically active compounds, such as proteins, amino acids, polyunsaturated fatty acids, microelements, vitamins, antioxidants called carotenoids, which have long records of human application as a food (Belotti et al., 2014). Microalgae of exclusive species could be properly involved in poultry diets, which can affect advisably on birds' health, performance, and comfort of chickens' meat and egg (Abdelnour et al., 2019).

Microalgae were considered to be an adequate supply of a large number of metabolites that were suitable for animal feed. These metabolites included proteins, 
carbohydrates, fats, vitamins, and minerals (Andrade et al., 2018).

Currently, microalgae are receiving more attention in the market as nutraceuticals and fitness meals. Several microalgae, such as Spirulina, Chlorella, and Amphora are grown commercially for the production of algal products such as $\beta$-carotene, lutein, and phycocyanin (Hirata et al., 2000). Amphora is a major genus of diatoms of marine and freshwater origin (Parnell and Trevor, 2007).

Amphora coffeaeformis is one of the most common alkaline fresh ecosystems and brackish-water localities (Bhosleac et al., 1993). Amphoracoffeaformis has strong antioxidant activity against lipid peroxidation (Sugiharto et al., 2018), and is rich in polyunsaturated fatty acids (PUFAs), especially Docosahexaenoic (DHA), Eicosapentaenoic (EPA), and $\alpha$-linolenic acid (Lee et al., 2009).

The microalga was a source of bioactive compounds including Amphora coffeaeformis, especially the carotenoids, sulfated polysaccharides, polyunsaturated fatty acids, $\alpha$-tocopherol, especially $\beta$-glucans, in addition to vitamins $\mathrm{C}$ and $\mathrm{E}$ (El-Sayed et al., 2018)

Several studies on diatoms such as Amphora showed the possibility of their extract to use in both protective and antioxidant agents (Mekkawy et al., 2020), except for their antibacterial (Ayoub et al., 2019), antiviral (Abdel-Wahab, 2018), anti-inflammatory factors (Lauritano et al., 2016) and their dietary supplements (Selvaraj et al., 2013).

Amphora coffeaeformis was considered as a potent radical scavenger due to the presence of $\beta$-carotene and fucoxanthin, which are widely used as food additives in addition to the various nutraceutical applications such as pro-vitamin (Jaswir et al., 2011). The oral administration of Amphora coffeaeformis at three attentions (10,20, and $30 \mathrm{~g} / \mathrm{kg}$ diet) in Nile tilapia (O. niloticus) diets led to enhance in growth performance, feed efficiency, and serum lysozyme (Ayoub et al., 2019).

Herbs are mixed into poultry diets to replace synthetic products and to stimulate or promote the efficient use of feed nutrients, which may subsequently result in faster body weight gain, higher production rates, and increased feed efficiency. In addition, active ingredients in herbs could improve digestion and stimulate the immune functions of broilers (Ghazalah and Ali, 2008; Shawky et al., $2020 \mathrm{a}, \mathrm{b}$ ).

Star anise is a medium-sized evergreen tree that is native to southwest China and is also extensively cultivated in the subtropical and tropical regions of Asia (Benmalek et al., 2013; Elmasry et al., 2018). It has been shown that star anise promoted digestion, and has antioxidant, antibacterial, antiparasitic, antipyretic, and antifungal properties (Ertas et al., 2005; Mohammed, 2008).

However, anethole is an important compound in the Star anise, the other important compounds in the seeds include p-anisaldehyde, anise alcohol, acetophenone, pinene, and limonene. Seeds have excellent supplies of minerals such as calcium, iron, manganese, magnesium, zinc, potassium, and copper. This essential spice contains precise amounts of antioxidant nutritional vitamins such as vitamin C and vitamin A (Zhou et al., 2005). Shikimic acid, which is a component in Star anise, is one of the best components of the antiviral drug Tamiflu for combating avian influenza (Ohira et al., 2009; Borah, 2015). Star anise is pronounced to possess antioxidant residences (Chempakam and Balaji, 2008) as well as a tremendous anticancer (Shu et al., 2010).

\section{MATERIALS AND METHODS}

\section{Ethical approval}

The experimental design was approved by the Ethical Research Committee of the Faculty of Veterinary Medicine, the University of Sadat City, Egypt with approval number VUSC-014-2-18.

\section{Experimental animals}

The current study was conducted in the Department of Physiology, the University of Sadat City, Faculty of Veterinary Medicine, Sadat City, Egypt, on 270 Cobb broiler chickens that were one-day-old and had an average weight of $45.0 \pm 2.0$ gram (Cobb strain) of the Misr-ElArabia Company for Poultry.

Feed and water were supplied ad libitum, and synthetic lights were supplied 24 hours a day for the first 15 days to assist newly hatched chickens to commence drinking and eating. After two weeks, one hour of darkness was applied once a day. The chickens were reared at $33^{\circ} \mathrm{C}$ to $34^{\circ} \mathrm{C}$ for the first week, and then regularly decreased by $2-3^{\circ} \mathrm{C}$ per week until the temperature reached around 21 to $23^{\circ} \mathrm{C}$, while the relative humidity was maintained around 55 to 65 percent. Chickens were reared in the poultry house, equipped with feeders, drinkers, and wood shaves used as bedding material. Strict sanitation practices were applied during some stages of the experiment. The chickens were reared under comparable environmental conditions. The experimental house was warm, dry, and free from drafts. Sparkling air provided some sort of ventilation to remove excess moisture and ammonia from the facility. 


\section{Nutrition}

Chickens were feed starter rations that contained all of the necessary nutrients needed for maintenance, growth, and reproduction from day one to day 14 . At the beginning of the third-week, chickens fed on the finisher ration (Table 1).

Table 1. The ingredients and chemical analysis of basal diet of broiler chickens

\begin{tabular}{lcc}
\hline Ingredients and composition $(\%)$ & Starter & Finisher \\
\hline Corn & 55.59 & 61.07 \\
Soybean meal & 37.32 & 31.83 \\
Soy oil & 2.98 & 3.41 \\
Lime stone & 1.21 & 1.42 \\
Dicalcium Phosphate & 1.60 & 1.16 \\
DL. Methionine & 0.20 & 0.10 \\
*Vitamin and Minerals & 0.60 & 0.60 \\
Sodium chloride & 0.23 & 0.18 \\
Sodium bicarbonate & 0.27 & 0.23 \\
\hline Chemical Analysis (\%) & & \\
\hline Metabolizable energy(ME) kcal/kg & 2950 & 3050 \\
Crude Protein $(\%)$ & 21.20 & 19.16 \\
Lysine (\%) & 1.14 & 1.01 \\
Methionine (\%) & 0.50 & 0.39 \\
Methionine and Cysteine $(\%)$ & 1.03 & 0.84 \\
Available Methionine + Cysteine & 0.85 & 0.71 \\
(\%) & 0.93 & 0.90 \\
Calcium (\%) & 0.44 & 0.35 \\
Available Phosphate (\%) & & \\
\hline S & & \\
\hline
\end{tabular}

*Supplied per kilogram of diet: vitamin A, 1,500 IU; cholecalciferol, 200 IU; vitamin E, $10 \mathrm{IU}$; riboflavin, $3.5 \mathrm{mg}$; pantothenic acid10 mg; niacin, $30 \mathrm{mg}$; cobalamin, $10 \mu \mathrm{g}$; choline chloride, $1,000 \mathrm{mg}$; biotin, $0.15 \mathrm{mg}$; folic acid, $0.5 \mathrm{mg}$; thiamine $1.5 \mathrm{mg}$; pyridoxine $3.0 \mathrm{mg}$; iron, $80 \mathrm{mg}$; zinc, $40 \mathrm{mg}$; manganese, $60 \mathrm{mg}$; iodine, $0.18 \mathrm{mg}$; copper, $8 \mathrm{mg}$; selenium, $0.15 \mathrm{mg}$.

\section{Preparation of Amphora coffeaeformis extract}

Amphoracoffeaeformis extract was obtained from the Algae Production Unit (APU), National Research Institute (center), Cairo, Egypt. The extract was previously identified for its phytochemical constitute using liquid chromatography-mass spectrometry (Mekkawy et al., 2020).

\section{Preparation of Star anise}

The dried Star anise was purchased from a local market and was added to the diet after grinding into powder.

\section{Animal grouping}

From the seventh day of the experiment, the chickens were divided into three groups with three replicates of 30 birds each. The chickens were raised on the floor with given water and diet ad libitum. All chickens were vaccinated against Newcastle Disease (ND) and Infectious Bronchitis (IB) strains HIB120 at ninth days of age and against infectious bursal disease (Gumboro) at the $13^{\text {th }}$ day of age. From day 16 to 35 , no vaccination was given against any disease. Chickens were randomly divided into three experimental groups, including group 1 (control group), which chickens only received basic ration; group 2, which ration was mixed with Amphora at a dose of $1 \mathrm{~g} / \mathrm{kg}$ feed (Mekkawy et al., 2020), and group 3, in which the chickens received a ration mixed with Star anise at a dose of $2 \mathrm{~g} / \mathrm{kg}$ feed (Alhajj et al., 2015; Ding et al., 2017).

\section{Growth performance parameters}

The growth performance parameters of broiler chickens have consisted of Body Weight (BW, gram), Body Weight Gain (BWG), Feed Intake (FI), and Feed Conversion Ratio (FCR). All chickens in groups had been weighed individually at the start and the end of the experiment. The body weight gain of chickens (expressed in grams) in each group was calculated by the difference between 2 successive weights (Nwanna, 2003).

Weight gain $=(\mathrm{W} 2-\mathrm{W} 1)$

Where $\mathrm{W} 1$ is the mean chicken weight at the beginning of the experiment and W2 is the mean chicken weight at the end of the experiment.

The experimental diets were offered regularly to each group. The feeds offered were measured daily, and at the end of the week, the weekly feed consumption was determined by the difference between the weight of feed offered and remained part. The FCR was calculated by dividing the amount of FI (g) during the entire experimental period by the total BWG (g) as outlined by Abd El-Wahed (1998).

$\mathrm{FCR}=$ total FI $(\mathrm{g})$ of chicken / total BWG $(\mathrm{g})$ of chicken.

\section{Sample collection}

On day 35, blood samples were taken from the wing vein of 10 chickens per group with anticoagulant (EDTA) to obtain plasma. The plasma was separated from the blood cells by centrifugation at 3.000 rounds per minute (rpm) for 30 minutes to determine haematological and biochemical parameters. Thereafter, chickens were slaughtered, and then the liver, and spleen were removed 
to estimate the mRNA expression of GH, IGF-1, IFN- $\gamma$, IL - 12p35 according to Cinthia et al. (2013).

\section{Determination of haematological parameters}

Red Blood Cells (RBCs), White Blood Cells (WBCs), Haemoglobin (Hb) concentration, and Packed Cell Volume (PCV) were estimated using automated technical analyserDirui Bcc-3600. The Mean Corpuscular Volume (MCV), Mean Corpuscular Haemoglobin $(\mathrm{MCH})$, and Mean Corpuscular Haemoglobin Concentration (MCHC) were determined according to the method describing by Feldman et al. (2000). Differential leukocyte counts (heterophils, eosinophils, basophils, lymphocytes, and monocytes) were counted on blood smears stained with May-Grunwald-Giemsa (Tavares-Dias and Moraes, 2003). Phagocytosis of polymorph nuclear cells using Candida Albicans was performed in accordance with the method described by Sornplang et al. (2015).

Phagocytic Activity $\%=($ Number of Heterophils ingesting candida $\times 100)$ / Total number of Heterophils.

Phagocytic index $=$ The total number of ingested candida / Number of active Heterophils.

\section{Determination of biochemical parameters}

The assay of total plasma proteins $(\mathrm{g} / \mathrm{dl})$ and albumin (g/dl) was carried out by a colorimetric method using commercial Diamond diagnostics kits according to the method described by Cannon et al. (1974) and Doumas et al. (1971), respectively.Serum alanine aminotransferase (ALT) and serum aspartate aminotransferase (AST) enzymes were determined colorimetrically using commercial kits of Bio diagnostics according to Reitman and Frankel, (1957). Creatinine (mg/dl) was determined by the colorimetric method using commercial kits of Biomed diagnostics according to Young (2001).Urea (mg/dl) was measured by the colorimetric method using commercial kits of Diamond diagnostics according to the method of Chaney et al. (1962). Protein electrophoresis profile was carried out by a Polyacrylamide Gel Electrophoresis according to Lewis et al. (2006).

\section{Gene expression}

Analysis of the mRNA expression of genes of Hepatic Growth Hormone and Insulin-like Growth Factor-1

The analysis of the mRNA of the expression of Growth Hormone (GH) and Insulin Growth Factor-1 (IGF1) was performed at the Central Laboratory of the Faculty of Veterinary Medicine, Benha University, in Egypt. Liver samples were dissected from each group and then immediately frozen at $-80^{\circ} \mathrm{C}$. Total RNA was extracted from the frozen liver using the RNeasy ${ }^{\circledR}$ Mini kit (Qiagen) according to the manufacturer's protocol. The quantity and quality of RNA were determined using SPECTROstar Nanodrop. Single-stranded cDNA was synthesized from $1000 \mathrm{ng}$ of total RNA according to the manufacturer's protocol for High-Capacity cDNA Reverse Transcription Kit (Applied Biosystems). The cycling conditions were 10 minutes at $25^{\circ} \mathrm{C}, 120$ minutes at $37^{\circ} \mathrm{C}$, and 5 minutes at $85^{\circ} \mathrm{C}$. Total RNA and cDNA samples were then stored at $-80^{\circ} \mathrm{C}$ until used. Expression of hepatic GH and IGF-1 genes was analyzed by real timePCR using sense and antisense primers as previously described (Gasparino et al., 2014) by using the primers sets including GH sense (5 'AAGGGATCCAAGCTCCTGAT-3'), and antisense (5 'ATAACCACGTCCCTCAGTGC-3'); IGF-1 sense (5 -' CACCTAAATCTGCACGCT-3'), and antisense (5 CTTGTGGATGGCATGATCT- ${ }^{\prime}$ ); and $\beta$ actin as a housekeeping gene, sense (5ACCCCAAAGCCAACAGA3 ') and anti-sense (5 - CCAGAGTCCATCACAATACC3 '). PCR reactions for each gene were performed for each sample analyzed. Each PCR reaction consisted of $1.5 \mu 1$ of $1 \mu \mathrm{g} / \mu 1 \mathrm{cDNA}, 10 \mu 1$ SYBR Green PCR Master Mix (QuantiTect SYBR Green PCR Kit, Qiagen), and one $\mu$ Mof each forward and reverse primer for GH and IGF-1 genes while one $\mu \mathrm{M}$ forward and $1.5 \mu \mathrm{M}$ reverse primer for $\beta$ actingene and nuclease-free water to a final volume of $20 \mu \mathrm{l}$. The reactions were then analyzed on an Applied Biosystems 7500 Fast Real-time PCR Detection system under the conditions of $95^{\circ} \mathrm{C}$ for ten minutes (holding stage) and 40 cycles of $95^{\circ} \mathrm{C}$ for 15 seconds (denaturation stage) followed by $60^{\circ} \mathrm{C}$ for one minute (annealing and extension stage). Changes in gene expression were calculated from the obtained Cycle threshold $(\mathrm{Ct})$ values, which were provided by real-time PCR instrumentation using the comparative Threshold cycle (TC) method for a reference (housekeeping) gene ( $\beta$ actin) (Gasparino et al., 2014).

\section{Analysis of mRNA expression of splenic interferon- gamma and Interleukin 12 genes}

Spleen samples were dissected from all groups and then immediately frozen at $-80^{\circ} \mathrm{C}$. Total RNA was extracted from the frozen spleen using the RNeasy ${ }^{\circledR}$ Mini kit (Qiagen) according to the manufacturer's protocol. The quantity and quality of the RNA were determined by using Spectrostar nanodrop Single-stranded cDNA was synthesized from $1000 \mathrm{ng}$ of total RNA according to the manufacturer's protocol for High Capacity cDNA Reverse 
Transcription Kits (Applied Biosystems). Cycling conditions were $25^{\circ} \mathrm{C}$ for 10 minutes, $37^{\circ} \mathrm{C}$ for 120 minutes, and $85^{\circ} \mathrm{C}$ for 5 minutes. Afterward, total RNA and cDNA samples were stored at $-80^{\circ} \mathrm{C}$ until use. Each PCR reaction consisted of $1.5 \mu \mathrm{l}$ of one $\mu \mathrm{g} / \mu \mathrm{l} \mathrm{cDNA}$, ten $\mu \mathrm{l}$ SYBR Green PCR Master Mix (QuantiTect SYBR Green PCR Kit, Qiagen), one $\mu \mathrm{M}$ of each forward and reverse primer for INF- $\gamma$ and IL-12p35 genes while one $\mu \mathrm{M}$ of forward and $1.5 \mu \mathrm{M}$ reverse primer for $\beta$ actin gene and nuclease-free water to a final volume of $20 \mu \mathrm{l}$. The Reactions were then analyzed on the Applied Biosystem 7500 Fast Real-time PCR Detection system under the conditions of $95^{\circ} \mathrm{C}$ for ten minutes (holding stage) and 40 cycles of $95^{\circ} \mathrm{C}$ for 15 seconds (denaturation stage) followed by $60^{\circ} \mathrm{C}$ for one minute (annealing and extension stage). Changes in gene expression were calculated from the obtained Cycle threshold $(\mathrm{Ct})$ values provided by realtime PCR instrumentation using the comparative CT method for a reference (housekeeping) gene (ßactin) (Gasparino et al., 2014).

\section{Statistical analysis}

The results were expressed as Mean \pm Standard Error (SE). The relations between means in different groups were tested using a one-way analysis of variance (ANOVA). Duncan test was used for finding the significant differences in SPSS, 16 version. The P-values at 0.05 or lesser were considered significant.

\section{RESULTS}

The data in table 2 presented that the Amphora and Star anise supplementation resulted in a significant increase $(\mathrm{p}$ $<0.05)$ in the final BW, BWG, and also a significant decrease in the FCR compared to the control group ( $\mathrm{p}<$ 0.05). The data in table 3 indicated that the Amphora and Star anise supplement did not significantly affect the erythrogram. The data in table 4 revealed that the Amphora and Star anise supplementation resulted in a significant increase $(\mathrm{p}<0.05)$ in total WBCs count, percentage of heterophils, H/L ratio, globulins (alpha 1 globulin, alpha 2 globulin, beta globulin, and gamma globulin), IgG, IgM, phagocytic activity, phagocytic index, while the total protein and albumin, lymphocyte percentage, and platelets count were not significantly affected. The data in table 5 revealed that the Amphora and Star anise supplementation did not significantly affect urea, creatinine, AST, and ALT ( $\mathrm{p}>0.05)$. The data in table 6 revealed that the Amphora and Star anise supplementation significantly increasedthe expression of hepatic GH and IGF1, and increased splenic INF-Gamma and interleukin $12 \mathrm{p} 35$ compared to the control group $(\mathrm{p}>0.05)$.

Table 2. Effect of Amphora and Star anise supplementation on growth performances of broiler

\begin{tabular}{lccc}
\hline Groups & Control group & Amphora group & Star anise group \\
\hline Initial body weight $(\mathrm{g})$ & $192.83 \pm 1.37 \mathrm{a}$ & $195.08 \pm 1.23 \mathrm{a}$ & $194.01 \pm 1.30 \mathrm{a}$ \\
Final body weight $(\mathrm{g})$ & $2054.9 \pm 6.74 \mathrm{c}$ & $2529.3 \pm 10.20 \mathrm{a}$ & $2297.8 \pm 10.59 \mathrm{~b}$ \\
Weight gain $(\mathrm{g})$ & $1824.60 \pm 11.79^{\mathrm{c}}$ & $2349.90 \pm 12.67^{\mathrm{a}}$ & $2195.90 \pm 17.55^{\mathrm{b}}$ \\
FCR & $2.43 \pm 0.03^{\mathrm{a}}$ & $1.62 \pm 0.01^{\mathrm{c}}$ & $1.82 \pm 0.02^{\mathrm{b}}$ \\
\hline
\end{tabular}

In the same row, Mean \pm Standard Error with different letters superscripts are significantly different at $\mathrm{P}<0.05$. FCR: Feed Conversion Rate.

Table 3. Effect of Amphora and Star anise supplementation on erythrogram of broiler

\begin{tabular}{lccc}
\hline Groups & Control group & Amphora group & Star anise group \\
\hline RBCs count $\left(10^{6} / \mathrm{mm}^{3}\right)$ & $2.45 \pm 0.08^{\mathrm{a}}$ & $2.60 \pm 0.06^{\mathrm{a}}$ & $2.59 \pm 0.07^{\mathrm{a}}$ \\
$\mathrm{PCV} \%$ & $29.06 \pm 0.61^{\mathrm{b}}$ & $30.94 \pm 0.49^{\mathrm{a}}$ & $29.59 \pm 0.62^{\mathrm{ab}}$ \\
$\mathrm{Hb}(\mathrm{g} / \mathrm{dl})$ & $11.29 \pm 0.20^{\mathrm{a}}$ & $11.68 \pm 0.21^{\mathrm{a}}$ & $11.61 \pm 0.17^{\mathrm{a}}$ \\
$\mathrm{MCV}\left(\mu^{3}\right)$ & $111.50 \pm 1.94^{\mathrm{a}}$ & $116.29 \pm 1.62^{\mathrm{a}}$ & $116.40 \pm 1.82^{\mathrm{a}}$ \\
$\mathrm{MCH}(\mathrm{Pg})$ & $38.94 \pm 0.62^{\mathrm{a}}$ & $38.04 \pm 0.85^{\mathrm{a}}$ & $37.86 \pm 0.70^{\mathrm{a}}$ \\
$\mathrm{MCHC} \%$ & $30.73 \pm 0.27^{\mathrm{a}}$ & $31.45 \pm 0.30^{\mathrm{a}}$ & $30.64 \pm 0.39^{\mathrm{a}}$ \\
\hline
\end{tabular}

In the same row, Mean \pm Standard Error with different letters superscripts are significantly different at $\mathrm{p}<0.05$. RBCs: Red Blood Cells; PCV: Packed Cell Volume; MCV: Mean Corpuscular Volume; MCH: Mean corpuscular hemoglobin; MCHC: Mean Corpuscular Hemoglobin Concentration. 
Table 4. Effect of Amphora and Star anise supplementation on immunity profile of broiler chicken

\begin{tabular}{|c|c|c|c|}
\hline Groups & Control group & Amphora group & Star anise group \\
\hline WBCs count $\left(10^{3} / \mathrm{mm}^{3}\right)$ & $20.55 \pm 0.17^{\mathrm{c}}$ & $32.99 \pm 0.41^{\mathrm{a}}$ & $29.03 \pm 0.42^{b}$ \\
\hline Lymphocytes (\%) & $68.65 \pm 0.74^{\mathrm{a}}$ & $67.80 \pm 0.31^{\mathrm{a}}$ & $67.63 \pm 0.32^{\mathrm{a}}$ \\
\hline Heterophils (\%) & $17.62 \pm 0.34^{\mathrm{c}}$ & $27.01 \pm 0.19^{\mathrm{a}}$ & $23.73 \pm 0.32^{\mathrm{b}}$ \\
\hline $\mathrm{H} / \mathrm{L}$ ratio & $0.40 \pm 0.003^{\mathrm{a}}$ & $0.35 \pm 0.006^{\mathrm{b}}$ & $0.30 \pm 0.007^{\mathrm{c}}$ \\
\hline Platelets count $\left(10^{3} / \mathrm{mm}^{3}\right)$ & $310.25 \pm 11.51^{\mathrm{a}}$ & $298.25 \pm 9.20^{\mathrm{a}}$ & $310.85 \pm 8.01^{\mathrm{a}}$ \\
\hline Total plasma protein $(\mathrm{g} / \mathrm{dl})$ & $3.32 \pm 0.03^{\mathrm{a}}$ & $3.47 \pm 0.07^{\mathrm{a}}$ & $3.41 \pm 0.06^{\mathrm{a}}$ \\
\hline Albumin (g/dl) & $1.83 \pm 0.03^{\mathrm{a}}$ & $1.67 \pm 0.06^{\mathrm{a}}$ & $1.72 \pm 0.06^{\mathrm{a}}$ \\
\hline Globulin (g/dl) & $1.50 \pm 0.02^{\mathrm{c}}$ & $1.80 \pm 0.02^{\mathrm{a}}$ & $1.68 \pm 0.02^{\mathrm{b}}$ \\
\hline Alpha 1 globulin (g/dl) & $0.24 \pm 0.003^{\mathrm{c}}$ & $0.34 \pm 0.006^{\mathrm{a}}$ & $0.32 \pm 0.008^{b}$ \\
\hline Alpha 2 globulin (g/dl) & $0.32 \pm 0.004^{\mathrm{a}}$ & $0.32 \pm 0.004^{\mathrm{a}}$ & $0.33 \pm 0.005^{\mathrm{a}}$ \\
\hline Beta globulin (g/dl) & $0.42 \pm 0.004^{c}$ & $0.48 \pm 0.010^{\mathrm{a}}$ & $0.45 \pm 0.004^{\mathrm{b}}$ \\
\hline Gamma globulin (g/dl) & $0.51 \pm 0.016^{\mathrm{c}}$ & $0.66 \pm 0.009^{\mathrm{a}}$ & $0.60 \pm 0.018^{b}$ \\
\hline $\operatorname{IgM}(\mathrm{mg} / \mathrm{dl})$ & $50.02 \pm .0 .8^{c}$ & $90.02 \pm 0.5^{\mathrm{a}}$ & $80.47 \pm 1.4^{\mathrm{b}}$ \\
\hline $\operatorname{IgG}(\mathrm{mg} / \mathrm{dl})$ & $20.95 \pm 0.7^{\mathrm{c}}$ & $40.37 \pm 0.5^{\mathrm{a}}$ & $40.14 \pm 0.4^{\mathrm{b}}$ \\
\hline $\mathrm{A} / \mathrm{G}$ ratio & $1.22 \pm 0.03^{\mathrm{a}}$ & $0.93 \pm 0.04^{\mathrm{b}}$ & $1.03 \pm 0.04^{\mathrm{b}}$ \\
\hline Phagocytic activity (\%) & $49.79 \pm 0.72^{\mathrm{c}}$ & $67.73 \pm 0.73^{\mathrm{a}}$ & $63.69 \pm 0.46^{\mathrm{b}}$ \\
\hline Phagocytic index & $1.93 \pm 0.050^{\mathrm{c}}$ & $2.83 \pm 0.040^{\mathrm{a}}$ & $2.67 \pm 0.026^{\mathrm{b}}$ \\
\hline
\end{tabular}

In the same row, Mean \pm Standard Error with different letters superscripts are significantly different at $\mathrm{p}<0.05$. WBCs: White Blood Cells; IgM: Immunoglobuline M; IgG: Immunoglobuline G; A/G ratio: albumin / globulin ratio; H/L ratio: Heterophils/ Lymphocytes ratio.

Table 5.Effect of Amphora and Star anise supplementation on liver function tests and kidney function tests of broiler

\begin{tabular}{lccc}
\hline Groups & Control group & Amphora group & Star anise group \\
\hline ALT (U/L) & $191.60 \pm 4.35^{\mathrm{a}}$ & $183.30 \pm 3.67^{\mathrm{a}}$ & $187.60 \pm 2.97^{\mathrm{a}}$ \\
AST(U/L) & $36.60 \pm 1.21^{\mathrm{a}}$ & $33.90 \pm 1.10^{\mathrm{a}}$ & $33.30 \pm 1.15^{\mathrm{a}}$ \\
Urea (mg/dl) & $9.29 \pm 0.10^{\mathrm{a}}$ & $8.91 \pm 0.13^{\mathrm{a}}$ & $9.35 \pm 0.13^{\mathrm{a}}$ \\
Creatinine(mg/dl) & $0.45 \pm 0.010^{\mathrm{a}}$ & $0.42 \pm 0.005^{\mathrm{a}}$ & $0.44 \pm 0.006^{\mathrm{a}}$ \\
\hline
\end{tabular}

In the same row, Mean \pm Standard Error with different letters superscripts are significantly different at $\mathrm{p}<0.05$.ALT: Serum alanine aminotransferase; AST: serum aspartate aminotransferase.

Table 6.Effect of Amphora and Star anisesupplementation on mRNA expression of growth hormone, Insulin-like growth factor1, Interferon gamma, Interleukin12p35 of broiler chicken, data represented as fold change among different experimental groups

\begin{tabular}{lccc}
\hline Groups & Control group & Amphora group & Star anise group \\
\hline GH & $1.27 \pm 0.11^{\mathrm{b}}$ & $9.11 \pm 0.13^{\mathrm{a}}$ & $8.25 \pm 0.21^{\mathrm{a}}$ \\
IGF1 & $1.05 \pm 0.03^{\mathrm{b}}$ & $3.78 \pm 0.08^{\mathrm{a}}$ & $2.73 \pm 0.08^{\mathrm{a}}$ \\
INF gamma & $1.25 \pm 0.03^{\mathrm{b}}$ & $7.60 \pm 0.15^{\mathrm{a}}$ & $6.36 \pm 0.06^{\mathrm{a}}$ \\
IL - 12p35 & $0.90 \pm 0.04^{\mathrm{b}}$ & $2.14 \pm 0.06^{\mathrm{a}}$ & $1.81 \pm 0.05^{\mathrm{a}}$ \\
\hline
\end{tabular}

In the same row, mean \pm Standard Error with different letters superscripts are significantly different at P < 0.05 . GH: hepatic growth hormone; IGF-1: insulinlike growth factor-1; INF- $\gamma$ : splenic interferon-gamma; IL-12p35: Interleukin12p35.

\section{DISCUSSION}

Poultry meat is the second largest food product in the world (Manning et al., 2007). In order to endure poultry production the meet global demand, antibiotic replacements were required (Mcdevitt et al., 2006). In the present study, chickens that were fed a diet supplemented with Amphora coffeaeformis and Star Anise significantly enhanced their growth performance compared to the control group. This result is attributed to the fact that Amphora coffeaeformis significantly improved appetite, which led to higher FI and improved growth (Ayoub et al., 
2019). These results were compatible with those reported by Zhao et al. (2004), who concluded that Amphoratreated chickens indicated an increased average daily gain and an improvement in the FCR due to the improvement in the digestibility of nutrients.

The improvement in the FCR could also be due to the fact that Amphora coffeaeformis contained several nutrients, especially vitamins and minerals that could aid in promoting growth (Belay et al., 1996). The positive effects of Amphora could be due to its bioactive compounds, which have antioxidant, anti-inflammatory, antiviral, and antibacterial effects (Rajput and Mishra, 2012; Salahuddin et al., 2017).

Star anise had a positive effect on the live BW, BWG, and FCR of broiler chickens (Al-hajj et al., 2015). The improvement in broiler performance could be due to the active component in Star anise, anethole, which could lead to better digestion by inducing the secretion of endogenous enzymes, better absorption, and improved microbial balance in the gut. Amad et al. (2011) stated that the inclusion of essential oils from thyme and Star anise resulted in an improvement of the digestibility of the crude protein, crude ash, crude fat, calcium, and phosphorus. This enhancement in the digestibility also led to an increased surface area for absorption in the intestine and improved nutrient absorption. Additionally, it was found that essential oils had a stimulatory effect on pancreatic enzymes (Rao et al., 2003).

The present study revealed no significant difference in blood parameters between the treatment groups the control group. The present results were in agreement with Soltan et al. (2008) and Mekkawy et al. (2020), who reported that there were no significant differences in blood profiles in groups that supplemented with Star anise seed and Amphora.

In the present study, the addition of Amphora and Star anise improved the immunity indices in broilers such as phagocytic activity, gamma globulins, IgM, and IgG. Amphora coffeaeformisactivated the immune system of the chickens and became resistant to pathogenic bacteria, which was consistent with the finding of Mariey et al. (2012) and Jamil et al. (2015). This activation of the immune system could be due to Amphora, which was rich in different pigments and polyphenolic compounds, catechin, gallic acid, and p-coumaric acid (El-Sayed et al., 2018). Also, Jaswir et al. (2011) revealed that Amphora coffeaeformis was known to be a potent radical scavenger due to the presence of $\beta$-carotene and fucoxanthin, which were often used as food additives in addition to the various nutraceutical applications such as pro-vitamin A, antioxidant, anticancer, and anti-obesity.

Feeding chickens with Star anise resulted in a significant increase in the immunity indices of all groups. It might be due to the fact that Star anise modulates the immune system by stimulating various immune cells such as macrophages, monocytes, Natural Killer Cell (NKC) and effects on cytokines/chemokines in various in vitro and in vivo trials (Shahrajabian et al., 2019; Sung et al., $2012 \mathrm{a}, \mathrm{b})$.

The results of Amohora which activated the immune system agreed with Kang et al. (2013), who found a significant increase in the lymphocyte counts in algae-fed broilers compared to other chickens. The phagocytic activity was also significantly increased in treated animals that were fed with algae and improved the immune response (An et al., 2010). Also, Khan et al. (2012) reported that the immunomodulatory effects of natural feed additives were linked to their ability to increase phagocytosis of potential macrophages, the production of interleukins, interferon-Y, and tumor necrosis factor, increase the secretory metabolism of macrophages, antigen-presenting cells, and antioxidant functions.

The present findings were in accordance with Abdelnour et al. (2019), who noted that $\operatorname{IgG}$ and $\operatorname{IgM}$ levels were increased in broilers that consumed food containing algae. Immunoglobulins increasing could be because several types of unicellular microalgae are excellent sources of immunoregulatory polysaccharides, such as $\beta$-glucan, $\beta$ carotene, and vitamin B12, which play a vital role in inflammatory and immune responses in animals and humans, which promote the macrophages activity and immune cells to increase the production of interferon- $\gamma$ protein. Therefore, Amphora could stimulate the ability of the immune system to fight against pathogens and foreign proteins (Mason, 2001), which were in accordance with (Abdo and Zeinb, 2004), who was indicated that the herbal supplements could improve the immune response since globulin levels were used as an indicator of immune responses and a source of antibody production. Soltan et al. (2008) reported that Star anise supplementation in the broiler diet significantly increased lymphocyte counts compared to the control group, possibly be due to an aromatic plant like Star anise seeds, which contain many essential B-complex nutritional vitamins such as pyridoxine, niacin, riboflavin, thiamine, and magnesium, copper, potassium, manganese, zinc, and iron. In addition, Star anise seeds contained the amounts of antioxidant nutritional vitamins, such as vitamin $\mathrm{C}$ and vitamin A (Zhou et al., 2016). Herbal Supplements could 
increase the immune response as globulin levels have been used as an indicator of immune responses and antibody sources (Abdo and Zeinb, 2004).

The immunity results were consistent with those of Rahmani and Speer (2005), who found a higher percentage of gamma globulins in broilers given herbal ingredients than the control ones. The present results revealed that there was no significant difference between ALT, AST, Urea, and Creatinine in the treated groups compared to the control group, which indicated that Amphora and Star anise appeared safe and did not have an adverse effect on physiological and nutritional status. Therefore, the utilization of algae in pharmaceutical applications has attracted world wild attention in recent years (Enwereuzoh and Onyeagoro, 2014). Star anise will contribute to the development of more phytotherapeutic products that are cheaper, safer, and affordable, and have a lower risk of resistance than conventional therapeutic drugs (Ritter et al., 2014; Sri et al., 2015).

In the current study, the mRNA expression of GH and IGF-1 was significantly increased in the treated chickens compared to the control chickens ( $\mathrm{p}<0.05)$. Growth hormones and IGF-1 are required to support normal growth (Scanes, 2009). Furthermore, animal growth is closely related to the mRNA expression levels, as intestinal nutrient transporters are required to circulate digestive products from digestion (McCracken and Edinger, 2013).

The results of the current study are compatible with those of Guobin et al. (2011), who reported that IGFs were important positive modulators of body and muscle growth in mammals and chickens.

In the current study, the splenic mRNA expression of IFN- $\gamma$ was significantly increased in the treated chickens in comparison with the control chickens and the housekeeping gene. Interferon- $\gamma$ regulated acquired immunity by stimulating lymphocytes and increasing the expression of class II antigens of Major Histocompatibility (MHC). In addition, IFN- $\gamma$ is a common marker of cellular immunity, and high levels have been correlated with protective immune responses to parasitic infections (Lee et al., 2008). Interferon-gamma (INF) influences the immune system and inhibits tumor growth, and are involved in various immune interactions as inducers, regulators, and effectors of both innate and acquired immunity during the infections (Priyanka and Muralidharan, 2014).

The molecular results of the present study indicated an increase of INF gene transcription levels in the spleen of the treated chickens compared to the control chickens. Blinkova et al. (2001) reported that algae are important positive stimulators for the production of antibodies, cytokines, and also $\mathrm{T}$ and $\mathrm{B}$ cell activation. Moreover, the available molecular results from INF agreed with Hirahashi et al. (2002), who reported that algae enhanced Natural killer cell functions by INF- $\gamma$ production and cytolysis. On the other hand, Mohammed AL (2014) stated a significant increase in the INF- $\gamma$ concentration in the blood serum of both groups of mice treated with two concentrations of herbal additives ( 1 and $5 \mathrm{mg} / \mathrm{kg} \mathrm{BW}$ ) compared to the control group. Also, Kim et al. (2010) and Lillehoj et al. (2011) reported that supplementing one-dayold chickens diets with medicinal plants indicated higher rates of interleukin interferon (IFN- $\gamma$ ), encoding gene transcripts in comparison with the chickens given a standard diet.

In the current study, the mRNA expression of the IL12 levels was significantly increased in the treated chickens compared to the control chickens. These results were in agreement with the results of Philbin et al. (2005), who reported that IL-12 differentiates T cells (Trinchieri, 1994), which is known as a factor that activates $T$ cells, that could promote the $\mathrm{T}$ cells growth and function. The activation of T cells enhances IFN- $\gamma$ development (Lesley et al., 2000). The present finding agreed with Ferdous et al. (2008) and Kirshenbaum et al. (2008), who found that adding the herbal additive to broilers' feed increased the expression of IL -12 .

\section{CONCLUSION}

The supplementation of Amphora coffeaeformis and Star anise to the diet of broiler chickens for 35 days was sufficient to improve broiler performance by improving $\mathrm{BW}, \mathrm{BWG}$, and FCR and to modulate their immunity through increasing total WBC count, the phagocytic activity percentage, the phagocytosis index in plasma, $\mathrm{IgM}$, and $\mathrm{IgG}$, in serum. In addition,Amphora and Star anise significantly increased the mRNA expression of the hepatic growth hormone gene, the insulin-like growth factor-1 (IGF-1) genes (IGF1), and the mRNA expression of splenic interferon-gamma (INF- $\gamma$ ), and Interleukin12 (IL-12p35) genes.

\section{DECLARATION}

\section{Acknowledgments}

We appreciate the Faculty of Veterinary Medicine of the University of Sadat City in Egypt.

\section{Competing interests}

The authors declared that they have no conflicts of interest. 


\section{Author's contribution}

Sherif Mohamed Shawky, Said Ibrahim Fathalla, and Sahar Hassan Orabi have participated in the creation of the conception, design, and writing of the manuscript. Sherif Mohamed Shawky, Said Ibrahim Fathalla, Sahar Hassan Orabi, Huda Hassan El-Mosalhi, and Ibrahim Said AbuAlya interpreted the data and reviewed the manuscript, while Huda Hassan El-Mosalhi and Ibrahim Said AbuAlya managed and analyzed the data. Huda Hassan ElMosalhi, Said Ibrahim Fathalla, and Ibrahim Said AbuAlya carried out the sampling and management of the samples.

\section{REFERENCES}

Abd El-Wahed HM (1998). The use of sorghum or rice bran in broiler and layer diets with reference to enzyme supplementation. $\mathrm{Ph}$. D. Thesis, Faculty of Agriculture, Fayoum, Cairo University, Egypt.Available at:www.fayoum.edu.eg/English/pgsr/AgriAbstractP73.aspx?AspxA utoDetectCookieSupport=1

Abdelnour SA, Abd El-hack ME, Arif M, Khafaga AF, and Taha AE (2019). The application of the microalgae Chlorella spp. as a supplement in broiler feed World's Poultry Science Association. World's Poultry Science Journal, 75:305-318. DOI: https://www.doi.org/10.1017/S0043933919000047

Abdel-Wahab AM (2018). In-vitro studies on antiviral effects of Galaxauraelongata marine algae on white spot syndrome virus, Benha Veterinary Medical Journal, 34(1): 162-171. Available at: https://bvmj.journals.ekb.eg/article_54231.html

Abdo M, and Zeinb A (2004). Efficacy of acetic acid in improving the utilization of low protein-low energy broiler diets. Egyptian Poultry Science, 24: 123-141.Available at: https://eurekamag.com/research/004/139/004139795.php

Al-hajj MS, Alhobaishi M, Ger El, Nabi AR, and Al-Mufarrej SI (2015). Immune responsiveness and performance of broiler chickens fed a diet supplemented with high levels of Chinese Star anise fruit (lfficiiimverum Hook. f).Journal of Animal and Veterinary Advances, $\quad$ 14(2): 36-42. Available at: https://medwelljournals.com/abstract/?doi=javaa.2015.36.42

Amad AA, Manner A, Wendler KP, Neumann K, and Zentek J (2011). Effects of a phytogenic feed additive on growth performance and ileal nutrient digestibility in broiler chickens. Poultry Science, 90: 2811-2816. DOI: https://www.doi.org/10.3382/ps.2011-01515

An HJ, Rim HK,Jeong HJ, Hong SH, Um JY, and Kim HM (2010). Hot water extracts of CLV vulgaris improve immune function in protein deficient weanling mice and immune cells. ImmunopharmacolImmunotoxicol, 32:585-592. DOI: https://www.doi.org/10.3109/08923971003604778

Andrade LM, Andrade CJ, Dias M, Nascimento CAO, and Mendes MA (2018). CLV and Spirulina Microalgae as Sources of Functional Foods, Nutraceuticals, and Food Supplements; an Overview. Food $\begin{array}{lll}\text { Processing and Technology, 6(1):144. DOI: } & \end{array}$ https://www.doi.org/10.15406/mojfpt.2018.06.00144

Ayoub HF, Abdelghany MF, and El-Sayed AB (2019). Effects of Diatoms Amphora coffeaeformis on growth parameters, nonspecific immunity, and protection of the Nile tilapia (Oreochromisniloticus) to Aeromonas hydrophila infection. Egyptian Journal of Aquatic Biology and amp; Fisheries, 23(1): 413-426. Available at:www.ejabf.journals.ekb.eg

Belay A, Kato T, and Ota Y (1996). Spirulina (Arthrospira): Potential application as an animal feed supplement. International Association of Applied Algology, 7th International Conference Abstracts, p. 23. Available at: https://link.springer.com/article/10.1007/BF02178573

Belotti G, Caprariis BD, Filippis PD, Scarsella M, and Verdone N (2014). Effect of Chlorella vulgaris growing conditions on bio-oil production via fast pyrolysis. Biomass Bioenerg, 61: 187-195. DOI: https://www.doi.org/10.1016/j.biombioe.2013.12.011

Benmalek Y, Yahia O, Belkebir A, and Fardeau ML (2013). Antimicrobial and anti-oxidant activities of Illicium verum, Crataegusoxyacanthasspmonogyna, and Allium cepa red and white varieties. $\quad$ Bioengineered, 244-248. DOI:https://www.doi.org/10.4161/bioe.24435.

Bhatta RS, and Sharma SR (2001). Nutrient utilization and growth performance of rabbit fed oat plant meal and tall fescue hay. AsianAustralasian Journal of Animal Science, 14:1228-1232. DOI: https://www.doi.org/10.5713/ajas.2001.1228

Bhosleac NB, Evansad LV, and Edyveanb RGJ (1993). Carbohydrate production by Amphora coffeaeformis, a marine fouling diatom. Biofouling, $7(1)$ : 81-91. https://www.doi.org/10.1080/08927019309386245

Blinkova LP, Gorobets OB, and Baturo AP (2001). Biological activity of Spirulina ZhMikrobiol Epidemiol Immunobiol, Mar-Apr. 8 (2): 108-114. . 2001 Mar-Apr; (2): 114-118. Review. In this review information of Spirulina platensis (SP), a blue-green alga (photosynthesizing cyanobacterium) having diverse biological activity is presented. Due to high content of highly. ZhMikrobiol Epidemiol Immunobiol, 2: 114-118. Available at:phytomedica.co.uk/pdf/immulina_herpes.pdf

Bolu SA, and Balogun OO (2004). Effects of improved (addition of antimicrobial and antioxidant) locally produced natural vitamin premix on the performance, nutrient retention, and carcass measurements of broilers. Centre Point, 10:83-92. DOI:http://www.dx.doi.org/10.5772/58342

Borah JC (2015). Shikimic acid: a highly prospective molecule in the pharmaceutical industry. Current Science, 109: 1672-1679. DOI: https://www.doi.org/10.18520/v109/i9/1672-1679

Cannon DC, Olitzky I, and Inkpen JA (1974). Proteins. In: Clinical chemistry, principles, and techniques. $2^{\text {nd }}$ edition. Harper and Row, New York, Pp. 407-421. DOI:https://www.doi.org/10.1016/09214488(95)00665-8.

Chaney AL, and Marbach EP (1962). Modified reagents for determination of urea and ammonia. Clinical chemistry, 8(2): 130132. Available at:https://academic.oup.com/clinchem/articleabstract/8/2/130/5672375

ChempakamB, and Balaji S (2008). Star Anise. United Kingdom: CAB International, pp. 319-330. DOI:https://www.doi.org/10.21475/ajcs.20.14.03.p2209

Cinthia E, Ricardo VN, and Paulo CP (2013). Carcass yield and sensorial analysis of meat from broiler chicken fed with tilapia by products meal.Ciência e Agrotecnologia, 37(5): 451-456. DOI: http://dx.doi.org/10.1590/S1413-70542013000500009

Ding IX, Yang CW, and Yang ZB (2017). Effects of Star anise (Illicium verum Hook. f.), essential oil, and leavings on growth performance, serum, and liver antioxidant status of broiler chickens. Journal of Applied Poultry Research, 26(4): 459-466. DOI: https://www.doi.org/10.3382/japr/pfx014.

Doumas BT, Watson WA, and Biggs HG (1971). Albumin standard and the measurement of serum albumin with bromocresol green, Clinicachimica acta, 31: 87-96. DOI: https://www.doi.org/10.1016/0009-8981(71)90365-2

Elmasry TA, Al-Shaalan NH Tousson E, El-Morshedy K, and AlGhadeer A (2018). Star anise extracts modulation of reproductive parameters, fertility potential, and DNA fragmentation induced by growth promoter Equigan in rat tests. Brazilian Journal of Pharmaceutical Sciences, 54:217-261. DOI: https://doi.org/10.1590/s2175-97902018000117261. 
El-Sayed AB, Aboulthana WM, El-Feky AM, Ibrahim NE, and Seif MM (2018). Bio and phytochemical effect of Amphora coffeaeformis extract against hepatic injury induced by paracetamol in rats, Molecular Biology Reports, 45:2007-2023. DOI: https://doi.org/10.1007/s11033-018-4356-8

Enwereuzoh UO, and Onyeagoro GN (2014). A novel aeration method for the preparation of algae (Dunaliella Salina) biomass for biofuel production. American Journal of Engineering Research, 3(9): 209214. Available at: https://scholar.google.co.uk

Ertas ON, Guler T, Iftci MC, Dalkilic B, and Simsek G (2005). The effect of an essential oil mix derived from oregano, clove and anise on broiler performance. International Journal of Poultry Science, 11: 879-884.

Feldman BF, Zinkl JG, and Jain NC (2000). Schalm's Veterinary Hematology, 5th edition, Philadelphia, Pp. 21-28. Available at:https://cmc.marmot.org/Record/.b21373000

Ferdous F, Maurice D, and Scott T (2008). Broiler chickens thrombocyte response to lipo polysaccharide. Poultry Science, 87:61-63. DOI: https://www.doi.org/10.3382/ps.2007-00356

Food and Agriculture Organization (2018). News Article: World's future food security "in jeopardy" due to multiple challenges, report warns Available at: http://www.fao.org/news/story/en/item/471169/icode/

Gasparino E, Del Vesco AP, Voltolini DM, Nascimento CS, Batista E, Khatlab AS, Grieser DO, Zancanela V, and Guimar ASE (2014). The effect of heat stress on GHR, IGF-I, ANT, UCP, and COXIII mRNA expression in the liver and muscle of high and low feed efficiency female quail. British Poultry Science, 55:466-73. DOI: https://doi.org/10.1080/00071668.2014.925090

Ghazalah A, and Ali A (2008). Rosemary leaves as a dietary supplement for growth in broiler chickens. International Journal of Poultry Science, 7: 234-239. Available at:https://scialert.net/abstract/?doi=ijps.2008.234.239

Guobin C, Xiangping L, and Jin L (2011). "Temporal and spatial expression of the Pax-7 gendering chicken embryo and postnatal development, " Journal of Animal and Veterinary Advances, 10: 1785-1788.

DOI:https://www.doi.org/10.3923/javaa.2011.1785.1788

Hirahashi T, Matsumoto M, Hazeki K, Saekia Y, Uic M, and Seyaa T (2002). Activation of the human innate immune system by Spirulina: augmentation of interferon production and NK cytotoxicity by oral administration of hot water extract of Spirulina platensis International Immunopharmacology, pp.423-434. DOI: https://doi.org/10.1016/S1567-5769(01)00166-7

Hirata T, Tanaka M, Ooike M, Tsunomura T, and Morihiko S (2000). Antioxidant activities of phycocyanobilin prepared from Spirulina platensis. Journal of Applied Phycology, 12: 435-439. Available at: https://link.springer.com/article/10.1023/A:1008175217194

Jamil ABMR, Akanda R, Rahman M, Hossain A, and Islam S (2015). Prebiotic competence of spirulina on the production performance of broiler chickens. Journal of Advanced Veterinary and Animal Research, 2: 304-309. DOI: http://dx.doi.org/10.5455/javar.2015.b94.

Jaswir I, Noviendri D, Hasrini RF, and Octavianti F (2011). Carotenoids Sources, medicinal properties, and their application in the food and nutraceutical industry. Journal of Medicinal Plants Research, 5(33): 7119-7131. DOI: https://www.doi.org/10.5897/JMPRX11.011.

Kang HK, Salim HM, Akter N, Kim DW, Kim JH, Bang HT, Kim MJ, Na JC, Hwangbo J, Choi HC et al. (2013). Effects of various forms of dietary CLV supplementation on growth performance, immune characteristics, and intestinal microflora population of broiler chickens. Journal of Applied Poultry Science, 22: 100-108. Available at: https://www.researchgate.net/publication/270080380 Effect of var ious forms of dietary Chlorella supplementation on growth per formance immune characteristics and intestinal microflora popu lation of broiler_chickens
Khan RU, Naz S, Nikousefat Z, Tufarelli V, and Laudadio V (2012). Thymus vulgaris: alternative to antibiotics in poultry feed. World Poultry Science Journal, 68: 401-408. DOI: https://www.doi.org/10.1017/S0043933912000517

Kim DK, Lillehoj HS, Lee SH, Jang SI, and Bravo D (2010). High-throughput gene expression analysis of intestinal intraepithelial lymphocytes after oral feeding of carvacrol, cinnamaldehyde, or Capsicum oleoresin. Poultry Science. 89: 6881. DOI: https://www.doi.org/10.3382/ps.2009-00275

Kirshenbaum AS, Swindle E, Kulka M, Wu Y, and Metcalfe DD (2008). Effect of lipopolysaccharide and peptidoglycan (PGN) on human mast cell numbers, cytokine production, and protease composition. BMC Immunology, 9:1-13. Available at: https://bmcimmunol.biomedcentral.com/articles/10.1186/14712172-9-45.

Lauritano C, Andersen, JH , Hansen E, Albrigtsen M, Escalera L, Esposito F, Helland K, Hanssen KØ, Romano G, Ianora A (2016). Bioactivity screening of microalgae for antioxidant, antiinflammatory, anticancer, anti-diabetes, and antibacterial activities, Frontiers in Marine Science, 3: 68. DOI: https://www.doi.org/10.3389/fmars.2016.00068

Lee SH, Karawita R, Affan A, Lee JB, Lee KW, Lee BJ, Kim DW, and Jeon YJ (2009). Potential of Benthic diatoms, Achnantheslongipes, Amphora coffeaeformis and Navicula sp. (Bacillariophyceae) as antioxidant sources. Algae, 24: 47-55. DOI: https://www.doi.org/10.4490/algae.2009.24.1.047

Lee SH, Lillehoj EP, Lillehoj SM, Cho DH, Park YH, Hong H, Chun K, and Park HJ (2008). Immunomodulatory properties of dietary plum on coccidiosis. Comparative Immunology, Microbiology, and Infectious Diseases, 31: 389-402. DOI: https://doi.org/10.1016/j.cimid.2007.06.005.

Lesley B, Blom JC, Timans Y, Xu B, Hunte F, Vega N, Yu J, Wang K, and Singh (2000). Novel p19 protein engages IL-12 p 40 to form a cytokine, IL-23, with biological activities similar as well as distinct from IL-12. Immunity, 13: $715 . \quad$ DOI: https://wwwdoi.org/10.1016/S1074-7613(00)00070-4

Lewis SM, Bain BJ, and Bates I (2006). "Dacie and Lewis Practical Hematology", $10^{\text {th }}$ edition, Philadelphia, Churchill Livingstone, pp. 335-355. Available at:https://www.worldcat.org/title/dacie-andlewis-practical-haematology/oclc/300300127

Lillehoj HS, Kim DK, Bravo DM, and Lee SH (2011). Effects of dietary plant-derived phytonutrients on the genome-wide profiles and coccidiosis resistance in the broiler chickens. BMC Proceeding, 5: $534 . \quad$ Available at: https://bmcproc.biomedcentral.com/articles/10.1186/1753-6561-5$\underline{\mathrm{S} 4-\mathrm{S} 34}$

Manning L, Baines RN, and Chadd SA (2007). Trends in the global poultry meat supply chain. British Food Journal, 109(5): 332-342. DOI: https://doi.org/10.1108/00070700710746759

Mariey Y, Samak H, and Ibrahem M (2012). Effect of using Spirulina platensis algae as a feed additive for poultry diets: 1-productive and reproductive performances of local laying hens." Egypt. Poultry Science, 32(1): 201-215. Available at: https://www.semanticscholar.org/paper/EFFECT-OF-USINGSPIRULINA-PLATENSIS-ALGAE-AS-AFEED-MarieySamak/22d0a2870cf60cdaf497b823cc6a617b9812ca2e

Mason R (2001). Chlorella and Spirulina: Green supplements for balancing the body. Alternative and Complementary Therapies, 7(3):161-165. Available at: https://www.liebertpub.com/doi/pdf/10.1089/107628001300303691

McCracken AN, and Edinger AL (2013). Nutrient transporters: the Achilles' heel of anabolism. Trends in Endocrinology and Metabolism. Science Direct, 24: 200-208. Available at: https://doi.org/10.1016/j.tem.2013.01.002.

Mcdevitt RM, Brooker JD, Acamovic T, and Sparks NHC (2006). Necrotic enteritis; a continuing challenge for the poultry industry. 
World's Poultry Science Journal, 62:221-247. https://doi.org/10.1079/WPS200593.

Mekkawy I, Mahmoud U, Moneeb R, and Sayed AED (2020). Significance assessment of Amphoracoffeaeformis in arsenicinduced hemato-biochemical alterations of African catfish (Clariasgariepinus), Frontiers in Marine Science, p.7. DOI: https://doi.org/10.3389/fmars.2020.00191

Mohammed AL (2014). Immunomodulatory effect of Curcuma longa in mice. Basrah Journal of Veterinary Research, 13(1): 222-234.

Mohammed GA (2008). The effect of anise and rosemary on broiler performance. International Journal of Poultry Science, 3: 243-245. DOI: https://www.doi.org/10.3923/ijps.2008.243.245

Nwanna LC (2003). Nutritional Value and digestibility of fermented shrimp head waste meal by African Catfish Claires gariepinus, Pakistan Journal of Nutritional, 2(6): 339-345.DOI: https://www.doi.org/10.1.1.487.9192and rep

Ohira H, Torii N, Aida TM, Watanabe M, and Smith RLJ (2009). Rapid separation of shikimic acid from Chinese Star anise (Illicium verum Hook. f.) with hot water extraction. Separation Purification Technology, 69: 102-108. DOI: https://doi.org/10.1016/j.seppur.2009.07.005.

Parnell J, and Trevor RH (2007). Reconstructing the tree of life: taxonomy and systematics of species-rich taxa. Boca Raton, 61, 3007-3011. DOI: $\underline{10.1201 / 9781420009538 . c h 17}$

Philbin V, Iqbal J, Boyd M, Goodchild Y, Beal JM, Bumstead KR, Young N, and Smith AL (2005). Identification and characterization of a functional, alternatively spliced Toll-like receptor 7 (TLR7) and genomic disruption of TLR8 in chickens. Immunology, 114: 507-521. DOI: https://doi.org/10.1111/j.1365-2567.2005.02125.

Priyanka R, and Muralidharan (2014). Interferons and interferon therapy. Journal Pharmaceutical Science and Research, 6: 400-403.

Rahmani HR, and Speer W (2005). Natural additives influence the performance and humoral immunity of broilers. International Journal of Poultry Science, 4(9):713-717. Available at: http://agris.fao.org/ID=DJ2012051528

Rajput R, and Mishra AP (2012). A review of biological activity of quinazolinones. International Journal of Pharmacy and Pharmaceutical Sciences, pp. 66-70. Available at: https://pdfs.semanticscholar.org/.

Rao RR, Platel K, and Srinivasan K (2003). In vitro influence of spices and spice-active principles on digestive enzymes of rat pancreas and small intestine. Nahrung, 4: 408-412. DOI: https://doi.org/10.1002/food.200390091.

Reitman S, and Frankel S (1957). A colorimetric method for the determination of serum glutamate oxaloacetic acid and pyruvic acid transaminases. American Journal of Clinical. Pathology, (29):5663.

Available at:https://www.scirp.org/(S(i43dyn45teexjx455qlt3d2q))/reference/ ReferencesPapers.aspx?ReferenceID $=1528104$

Ritter AMV, Ames FQ, Otani F, de Oliveria RMW, Cuman RKN, and Bersani-Amado CA (2014). Effects of anethole in Nociception experimental models. Hindawi Publishing Corporation, EvidenceBased Complementary and Alternative Medicine, Article ID 345829. P. 7. DOI:https://doi.org/10.1155/2014/345829

Salahuddin N, Elbarbary AA, and Alkabes HA (2017). Antibacterial and anticancer activity of loaded quinazolinone polypyrrole/chitosan silver chloride nanocomposite. International Journal of Polymeric Materials and Polymeric Biomaterials, 66: 307-316. DOI: https://www.doi.org/10.1080/00914037.2016.1201831

Scanes CG (2009). Perspectives on the endocrinology of poultry growth and metabolism. General and Comparative Endocrinology, 163: 2432. DOI: https://doi.org/10.1016/j.ygcen.2009.04.013.

Selvaraj V, Armistead MY, Cohenford M, and Murray E (2013). Arsenic trioxide (As2O3) induces apoptosis and necrosis mediated cell death through mitochondrial membrane potential damage and elevated production of reactive oxygen species in PLHC-1 fish cell line, $\quad$ Chemosphere, $\quad 90(3)$ : $\quad$ 1201-1209. DOI: https://doi.org/10.1016/j.chemosphere.2012.09.039.

Shahrajabian MH, Sun W, and Cheng Q (2019).Chinese Star anise and anise, magic herbs in traditional Chinese medicine and modern pharmaceutical scienceBiotechnology Research Institute, Chinese Academy of Agricultural Sciences, Beijing 100081, Asian Journal of Medical and Biological Research, 5(3): 162-179. DOI: https://doi.org/10.3329/ajmbr.v5i3.43584.

Shawky SM, Fathalla SI, Zahran IS, Gaafar KM, Hussein MK, and AbuAlya IS (2020b). The immunological stimulant effect of linseed oil and fennel oil supplemented diet on broilers. Advances in Animal and Veterinary Sciences, 8(7): 771-776.DOI । http://dx.doi.org/10.17582/journal.aavs/2020/8.7.771.776

Shawky SM, Orabi SH, and Dawod A (2020a). Effect of marjoram supplementation on growth performance and some immunological indices in broilers. International Journal of Veterinary Science, 9(2): 297-300. DOI: https://www.doi.org/10.37422/IJVS/20.026

Shu X, Liu XM, Fu CL, and Liang QX (2010). Extraction, characterization, and antitumor effect of the polysaccharides from Star anise Illicium verum (Hook f). Journal of Medicinal Plants Research,4: 2666-2673. DOI: https://www.doi.org/10.5897/JMPR09.438

Soltan MA, Shewita RS, and El-Katcha MI (2008). Effect of dietary anise seeds supplementation on growth performance, immune response, carcass traits, and some blood parameters of broiler chickens. International Journal of Poultry Science, 7: 10781088. DOI: https://www.doi.org/10.3923/ijps.2008.1078.1088

Sornplang P, Leelavatcharamas V, and Soikum C (2015). Heterophils Phagocytic Activity Stimulated by Lactobacillus salivarius L61 and L55 Supplementation in Broilers with Salmonella Infection. AsianAustralasian Journal of Animal Sciences, 28(11): 1657-1661. DOI: https://www.doi.org/10.5713/ajas.15.0359.

Sri PU, Leelavathi V, Sree VN, and Kumar MA (2015). Antihelmenthic and antimicrobial activity of green synthesized silver nanoparticles from Illicium Verum Hook. F. fruit. IOSR Journal of Pharmacy and Biological Sciences, 10: 61-65.Available at: https://www.semanticscholar.org/paper/Antihelmenthic-AndAntimicrobial-Activity-Of-Green-SriLeelavathi/9a8a70d393f464ee18e19d529c95f0dfbdf42e1c

Sugiharto S, Yudiarti T, Isroli I, and Widiastuti E (2018). Effect of feeding duration of Spirulina platensis on growth performance, hematological parameters, intestinal microbial population, and carcass traits of broiler chicks South African. Journal of Animal $\begin{array}{llll}\text { Science, } & 48(1) \text { : } & \text { 98-107. }\end{array}$ https://www.doi.org/10.4314/sajas.v48i1.12.

Sung YY, Kim YS, and Kim HK (2012a). Illicium verum extract inhibits TNF-n-and IFN-y-induced expression of chemokines and cytokines in human keratinocytes. Journal Ethnopharmacol, 144: 182-189. DOI: https://www.doi.org/10.1016/j.jep.2012.08.049

Sung YY, Yarig WK, Lee AY, Kim DS, Nho KJ, Kim YS, and Kim HK (2012b). The topical application of an ethanol extract prepared from Illicium verum suppresses atopic dermatitis in NC/Nga mice. Journal Ethnopharmacol, 144: 151-159. DOI: https://doi.org/10.1016/j.jep.2012.08.042.

Tavares-Dias M, and Moraes FR (2003). Hematological evaluation of Tilapia rendalli Boulenger, 1896 (Osteichthyes: Cichlidae) captured in a fee fishing farm from Franca, So Paulo, Brasil (in Portuguese). Bioscience Journal, 19: 103-110. Available at:https://agris.fao.org/agrissearch/search.do?recordID=BR2003004654

Trinchieri G (1994). Interleukin-12: a cytokine produced by antigenpresenting cells with immunoregulatory functions in the generation of T-helper cells type 1 and cytotoxic lymphocytes, Blood. 84: $4008 . \quad$ Available at:https://www.thermofisher.com/antibody/product/Human-IL12Recombinant-Protein/PHC1124. 
Young DS (2001). Effects of disease on the clinical lab. Tests, $4^{\text {th }}$ edition. AACC press, 48 (4): 682-683. Available at:https://www.scirp.org/(S(351jmbntvnsjt1aadkposzje))/reference/ ReferencesPapers.aspx?ReferenceID $=1272186$.

Zhang GF, Yang ZB, Wang Y, Yang WR, Jiang SZ, and Gai GS (2009). Effects of ginger root (Zingiber officinale) processed to different particle sizes on growth performance, antioxidant status, and serum metabolites of broiler chickens. Poultry Science, 88: 2159-2166. DOI: https://doi.org/10.3382/ps.2009-00165.

Zhao R, Muehlbauer E, Decuypere E, and Grossmann R (2004). Effect of genotype-nutrition interaction on growth and somatotropic gene expression in the chicken. General and Comparative
Endocrinology, $\quad 136: \quad 2-11 . \quad$ DOI: https://www.doi.org/10.1016/j.ygcen.2003.11.009

Zhou BG, Wang S, Dou TT, Liu S, Li MY, Hua, RM, Li SG and Lin HF (2016). Aphicidal activity of Illiumverum fruit extracts and their effects on the acetylcholinesterase and glutathione S-transferases activities in Myzuspersicae (Hemiptera: Aphididae). Journal of Insect Science, 16: 1-7. DOI: https://doi.org/10.1093/jisesa/iev163

Zhou CZ, Meyer P, Quevillon-Cheruel S, Li De La Sierra-Gallay I, Collinet B, Graille M., Blondeau K, François JM, and Sorel I (2005). Crystal structure of the YML079w protein from Saccharomyces cerevisiae reveals a new sequence family of the jelly-roll fold. Protein Science, 14(1):209-2015. Available at: https://www.ncbi.nlm.nih.gov/pmc/articles/PMC2253319/ 